\title{
Between radical geography and humanism: Anne Buttimer and the International Dialogue Project
}

\section{Federico Ferretti}

federico.ferretti@ucd.ie

This paper argues for a rediscovery and reassessment of the contributions that humanistic approaches can make to critical and radical geographies. Based on an exploration of the archives of Anne Buttimer (1938-2017) and drawing upon Paulo Freire's notion of conscientização (awareness of oppression accompanied by direct action for liberation), a concept that inspired the International Dialogue Project (1977-1988), I explore Buttimer's engagement with radical geographers and geographies. My main argument is that Buttimer's notions of 'dialogue' and 'catalysis', which she put into practice through international and multilingual networking, should be viewed as theory-praxes in a relational and Freirean sense. In extending and putting critically in communication literature on radical pedagogies, transnational feminism and the 'limits to dialogue', this paper discusses Buttimer's unpublished correspondence with geographers such as David Harvey, William Bunge, Myrna Breitbart, Milton Santos and others, and her engagement with radical geographical traditions like anarchism, repositioning 'humanism' vis-à-vis the fields of critical and radical geography.

Keywords: Anne Buttimer, Dialogue Project, Conscientização, Internationalism, Antipode, Radical Geography

'It is so strange to find someone saying very much the same thing as I am trying to say but saying it out of a completely different literature', UCD, Archives Anne Buttimer, USA 19671977, David Harvey to Anne Buttimer, 20 December 1969

In the last few years, several works have canonised so-called 'Humanistic Geographies' as a key contribution to the history of geographical ideas. In his book Geographic Thought, a Critical Introduction, Tim Cresswell argues that this movement's legacy and impact on recent trends, including 'a post-humanist geography' (Cresswell, 2013:119), still needs to be assessed.

F. Ferretti, 2019 "Between radical geography and humanism: Anne Buttimer and the International Dialogue Project", Antipode, 2019 early view: https://onlinelibrary.wiley.com/doi/full/10.1111/anti.12536 [author's pre-print version] 
Based on the first exploration of an exceptional collection of primary sources, the archives of Anne Buttimer (1938-2017) recently bequeathed at University College Dublin, this paper argues for a rediscovery of critical and radical insights coming from humanistic geographical traditions, especially from Buttimer's works. For this purpose, I explore Buttimer's engagement with critical and radical scholars and traditions in the 1970s and 1980s while drawing upon Paulo Freire's notion of conscientização (the act of being aware of oppression accompanied by direct action applied for liberation) (Freire 2000), a concept that inspired the International Dialogue Project that Buttimer led with Torsten Hägerstrand (1916-2004) from 1977 to 1988. My main argument is that Buttimer's notions of 'dialogue' and 'catalysis', which she put into practice through international and multilingual networking, should be intended as theory-praxes in a Freirean sense. This contributes to current discussions on researchers' social responsibilities within and outside of academia, which Buttimer defined as 'accountability and social justice' (Maddrell 2009:753). This also shows that the history of geography, a field of study of which Buttimer was an inspirer, introduces neglected subversive potentialities to foster the social and political relevance of the discipline.

In recent years, a range of definitions for 'humanistic geographies' has been provided in discussing the contributions of authors considered to have led this movement, namely Buttimer, Yi-Fu Tuan, David Ley, David Seamon, Edward Relph, Marwin Samuels and others (Adams, Hoelscher and Till 2001; Seamon and Lundberg 2017; Sharp 2009). One of their main contributions was a powerful challenge to the hegemony of quantitative geography and technocracy, which they defined as 'geography without [humans]' (Ley 1980) or 'the dance macabre of materialistically motivated robots' (Buttimer 1993:47), inspiring contemporary reflections on the place of human beings in more-than-human and more-than-representational worlds (McCormack 2017). Several authors historicise humanistic geographies, arguing that they largely vanished during the 1990s, when they conflated with the new tendencies of cultural geographies 'and then combined with neo-Marxism and postmodernism to form the "new cultural geography"' (Smith 2009:239). Jonathan Smith also argues that Buttimer's metaphor of the dance macabre was 'hyperbolic, since all geographers recognise that humans possess a capacity for change that robots do not' (Smith 2009:246). I would differently understand Buttimer's definitions by considering the ethical plans which they served and the historical

F. Ferretti, 2019 "Between radical geography and humanism: Anne Buttimer and the International Dialogue Project", Antipode, 2019 early view: https://onlinelibrary.wiley.com/doi/full/10.1111/anti.12536 [author's pre-print version] 
contexts in which they were inserted; as I show below, Buttimer was a fighter, and many statements from her which might seem metaphysical were part of her militant engagement in rethinking geography. An exploration of Buttimer's archive can serve to actively foster these legacies.

I must clarify a few methodological points. The first, Buttimer explicitly refused the label of 'humanistic geographer'. Therefore, I generally parenthesise the terms 'humanistic geography' and 'humanistic geographies'. Instead, I use as preferred definitions those of 'humanistic' and 'humane' approaches (to geography, academia and engaged scholarship) while drawing upon the tradition of the Humane Sciences as it was understood by authors such as Edward Carpenter and Pyotr Kropotkin (Carpenter 1897), whose recent scholarship discusses as a radical version of humanism related to anarchist geographies (Ferretti 2018a). Second, I limit my survey of primary sources to a period roughly defined as the 1970s and 1980s, characterised by the ideation and development of the Dialogue Project and by related international networking. Further research will fully explore other parts of these archives and Buttimer's work.

Humanistic geographers paralleled the critical exiting from quantitative approaches and spatial science by radical geographers such as David Harvey and William Bunge (Barnes 2009). I would suggest that this is not the only element of parallelism and porosity found between the complex and multifaceted nebulas defined as 'humanistic' and 'radical' geographies. Buttimer's student and collaborator for the Dialogue Project, in which he was employed as a 'catalyst', ${ }^{1}$ David Seamon defines the ethical and political concerns that first informed humanistic approaches as ‘the emancipatory potential of human reason' (Seamon and Lundberg 2017:3). Like Yi-Fu Tuan's interrogations on 'how a humanist geographer contributes to human welfare' (Tuan 1976:275), this appears as a militant claim to counter allegations of the 'uselessness' of humanistic approaches especially coming from the 'quantifiers'. This means that humanistic and radical traditions shared first some adversaries, namely the disciplinary hegemony of quantitative geography associated with technocracy and social conservatism.

F. Ferretti, 2019 "Between radical geography and humanism: Anne Buttimer and the International Dialogue Project", Antipode, 2019 early view: https://onlinelibrary.wiley.com/doi/full/10.1111/anti.12536 [author's pre-print version] 
However, this proximity between humanistic and radical traditions is only documented for certain authors and periods and could hardly be generalisable. A preliminary exploration of Buttimer's correspondence with the 'humanistic geographers' closer to her, such as Seamon and Ley, suggests that her commitment was unevenly shared in their circuits, albeit a similar proximity appears in some correspondences between Buttimer and Ley. For instance, the latter was a supporter of James S. Duncan's appointment at the University of British Columbia.2 Formerly at Syracuse, Duncan is considered by Don Mitchell (2000) as a key figure for radicals' critiques to superorganicism. He was also involved in the collective book Humanistic Geographies, Prospects and Problems that Ley edited with Marwin W. Samuels (1978). Crucially, letters from Ley and Samuels to Buttimer show how the first projected title for this work was Humanistic Orientations in Geography, intended as both a tribute and a response to David Harvey's Explanation in Geography. ${ }^{3}$ The list of contributors for that book shows few names of scholars considered as 'radicals' at that time (with the possible exception of Denis Wood), but many of them, like Robert Geipel, Iain Wallace or David Sopher, were scholars socially engaged in various ways: this shows how 'neutral' or socially disengaged geographies can be also challenged by scholars who do not bring explicit political labels.

Buttimer's later correspondences with Seamon help understanding the subversive charge that humanistic approaches could have in geography. In 1991, Seamon wrote to Buttimer complaining how, at the AAG meetings, 'the discipline seems to continue to be dominated by the positivists'. ${ }^{4}$ In 1993, things were going 'worse and worse. Geography has become little more than a GIS/remote sensing/highschool quiz technical program, it seems. With the Marxists/poststructuralists as a bit of intellectual entertainment'. ${ }^{5}$ There, Seamon was confirming his positions of 14 years earlier, when he asked Buttimer whether 'the technocrats [still were] well in charge' ${ }^{6}$ at Clark. Critiques of technocratic and anti-intellectual uses of technologies like GIS characterised likewise the international field of critical geographies in the 1990s (Pickles 1995). Again, one can argue that, in geography, it is possible to radically criticise the mainstream even taking distance from approaches which have been hegemonic at certain moments in the history of radical geographies, like Marxism.

F. Ferretti, 2019 "Between radical geography and humanism: Anne Buttimer and the International Dialogue Project", Antipode, 2019 early view: https://onlinelibrary.wiley.com/doi/full/10.1111/anti.12536 [author's pre-print version] 
This paper also participates in recent attempts made to reassess memories of radical geographies and geographers from the 1960s and 1970s, including the publication of the archives of the Union of Socialist Geographers Newsletter by the Antipode Foundation, ${ }^{7}$ publications dedicated to Neil Smith (Heynen et al. 2017; Mitchell 2014), and numerous works by Trevor Barnes, Nik Heynen and others on the exceptional figure of William Bunge (Bergmann and Morrill 2018; Barnes 2017; Barnes et al. 2011; Heynen 2013). Other works explore the contributions of radical geographers from the 'Global South' such as Milton Santos (Melgaço 2018, Melgaço and Prouse 2017, Ferretti 2018b, Ferretti and Viotto 2018) and the importance of international networks of solidarity and decolonisation (Craggs and Wintle 2016; Featherstone 2015). Crucially, Buttimer was acquainted with many of these radical scholars and was interested in their views. While she claimed that she did not 'play politics', she explicitly described herself with outstandingly political definitions as an 'Irish anticolonialist $^{8}$ and expressed overtly anti-capitalist ideas (Academia Europaea 2017). In this exploratory contribution, I show how Buttimer's humanism was disruptive and still able to nourish relevant critiques of the academic establishment. This allows for challenging criticisms according to which, relatedly, 'humanistic geographers ethically favoured place, insideness, and rootedness over non-place, outsideness, and mobility; place itself was assumed to be centred, static, bounded, and exclusionary' (Seamon and Lundberg 2017, 9). I would argue that such statements can be hardly generalised to all 'humanists' and surely not to Buttimer's works and biography. Several current tenants of English-speaking academia may learn something from Buttimer's cosmopolitism, multilingualism and international/transnational engagement.

Buttimer was one of the first figures of female geographers who got institutional recognition with appointments like that as the Chair of the International Geographical Union, where she fought to include underrepresented figures such as women, scholars from the 'Global South' and various kinds of unorthodox thinkers. Therefore, to assess networks and performances of the International Dialogue Project, I draw upon literature on transnational feminism which criticises statist conceptual frameworks, arguing that this corresponds to Buttimer's intentions in challenging the tradition of national geographical schools. In the first part of my paper, I discuss the relevance of conscientização as radical inspiration for the Dialogue Project, drawing upon contemporary literature on Paulo Freire, politics and geography. In the second

F. Ferretti, 2019 "Between radical geography and humanism: Anne Buttimer and the International Dialogue Project", Antipode, 2019 early view: https://onlinelibrary.wiley.com/doi/full/10.1111/anti.12536 [author's pre-print version] 
part, I discuss the Dialogue Project to explore Buttimer's internationalist practices as part of her scholarly and political agenda, through the lenses of recent scholarship in transnational feminism. In the third part, I analyse Buttimer's engagement with radical traditions including anarchism and her networking with radical scholars and broader debates that ensued. In conclusion, I show why we should rediscover today the values exposed through these experiences.

\section{Dialogue and coscientização}

Anne Buttimer was an exceptional transnational and cosmopolitan scholar. Born in County Cork from a farming family, after her studies, she took her vows as a Dominican nun (which she relinquished in 1976 for personal reasons). In this capacity, she could take a PhD at University of Washington in Seattle and travel extensively to Europe, performing research projects in Leuven (Belgium) and Glasgow (Scotland) on social geography. First tenured at Clark University, she spent several years in Sweden working under the Dialogue Project with Hägerstrand and after a period in Ottawa, she returned to Ireland in 1991 to serve as Chair of Geography at UCD, where she remained until her retirement (Clout 2017; Ferretti and Jones 2018). She claimed her rootedness in her land and her commitment to social Catholicism throughout her life (Maddrell 2009).

Paulo Freire (1921-1997) was a Brazilian educator and political dissident. Born in Recife, Pernambuco, the same place of origin of critical geographers Josué de Castro and Manuel Correia de Andrade (Ferretti 2018b), Freire was in touch with circuits of Brazilian geographers opposed to the 1964-1985 military dictatorship. Another figure very difficult to label, Freire is sometimes associated with Marxism (McLaren 2000) and sometimes with anarchism (Aronowitz 1993; Brunetto 2010; Codello 2005). While I would not assign any political label to Freire (or to Buttimer), I must stress the importance of his work for radicals of various kinds and its impact on the Dialogue Project.

In his most famous book Pedagogia do Oprimido, Freire first defined conscientização as an idea that frightened those afraid of freedom and that "calls attention to "the danger of conscientização" in a way that reveals their own fears of freedom. Critical consciousness, they

F. Ferretti, 2019 "Between radical geography and humanism: Anne Buttimer and the International Dialogue Project", Antipode, 2019 early view: https://onlinelibrary.wiley.com/doi/full/10.1111/anti.12536 [author's pre-print version] 
say, is anarchic' (Freire 2000:35). Such subversive potential is explained by the fact that conscientização means not only that the oppressed become aware of the oppression which they suffer (from the Capital, the State, the Church, educational institutions, etc.): it also implies active agency against it. In Freire's view, individual awareness is needed to eliminate all political or religious 'fanaticism': 'By making it possible for people to enter the historical process as responsible subjects, conscientização enrols them in the search for self-affirmation and thus avoids fanaticism' (Freire 2000:36). This argument directly recalls anarchist concerns for individual and collective liberation: in the anarchist tradition, the active deployment of individual critical capacities by all members of a group is one of the basic conditions needed to work in effectively egalitarian ways while preventing a popular movement from becoming a mass of people manipulated by formal or informal leaders (Ferretti 2016).

A definition that arguably interested Buttimer was Freire's claim for humanising social relations by way of 'a humanist and libertarian pedagogy' (Freire 2000:54) given that 'authentic liberation' was 'the process of humanisation' (Freire 2000:77). Therefore: 'Liberation is a praxis: the action and reflection of men and women upon their world in order to transform it' (Freire 2000:77), that is a theory put in practice by the oppressed through their actions from below. Stanley Aronowitz has called attention to frequent misunderstandings of Freire's views among European and North-American scholars, arguing that Freire's notion of pedagogy is not reducible to a teaching method or to the realm of formal education, as it is a whole philosophy of life, 'a secular liberation theology' (Aronowitz 1993:12). What is crucial here is that this comprehensive definition of education allowed Buttimer to view the Dialogue Project in Freirean terms: the idea of working with active or retired academics and professionals in terms of 'pedagogy' was not a banal one.

Significantly, several geographers' references to Freire are associated with one of Buttimer's correspondents, William Bunge, and eventually with the Detroit Geographical Expedition, which is considered to be an example of dialogue 'formed with oppressed urban groups [that is] the hub of Freire's argument' (Merrifield 1995:62). In 2007, Rich Heyman defined 'Paulo Freire's radical pedagogical theories' (Heyman 2007:105) as a drive towards the radicalisation of geography. Ronald J. Horvath opportunely observed that at the time of Bunge's work in

F. Ferretti, 2019 "Between radical geography and humanism: Anne Buttimer and the International Dialogue Project", Antipode, 2019 early view: https://onlinelibrary.wiley.com/doi/full/10.1111/anti.12536 [author's pre-print version] 
Detroit, "none of the teachers in the two geographical expeditions had read Freire prior to or during the teaching programmes-in part because the English translation of Pedagogy of the Oppressed was only available after the Detroit and East Lansing teaching programmes were finished' (Horvath 2016:102-103). Nevertheless, interest of Freire's work for radical geographies and pedagogies is undeniable as recently confirmed by editors and contributors of the book The Radicalization of Pedagogy, who consider Freire's Pedagogy of the Oppressed and Ivan Illich's De-schooling Society as 'two of the most notable and important contributions to the development of critical pedagogies' (Springer, Lopes and White 2016:6).

Unlike in the case of Detroit, it is possible to consider Freire's conscientização as serving as direct inspiration for the Dialogue Project, whose ideation can be read through Freirean lenses. This project spurred international, interdisciplinary and inter-professional communication between geographers and other scholars and professionals through group discussion and individual interviews on the social and philosophical sense of the work they executed with a strong emphasis on autobiography (Buttimer and Hägerstrand 1980; Buttimer 1986; Jones 2019). At that time, this initiative was something unique in the international panorama of social sciences: within the Dialogue Project, geographers took the lead of an interdisciplinary endeavour targeting cross-fertilization with exponents of other specialities, especially 'economists, demographers, technologists, and politicians ... philosophers, sociologists, and psychologists" (Buttimer and Hägerstrand 1980:4). What also looked 'revolutionary' was the notion that scholars were themselves objects of investigation (including self-investigation) within a relational framework eventually referred to as 'catalysis': this form of conscientização grounded in dialogue anticipated contemporary notions of participatory research. What first drove my attention to Buttimer's uses of conscientização were frequent references made to Freire in her unpublished letters to correspondents interested in the Dialogue Project. This served as a big help, as references to Freire are generally more synthetic in her published works of the same years, though she had already defined Freire's 'conscientização projects in Brazil and elsewhere' as 'valuable' and 'remarkable' in Values in Geography (Buttimer 1974:2). A strong commitment to 'awakening people's consciousness' in Freirean terms was claimed by Buttimer in her interview with Christina Nordin recorded for the Dialogue Project. ${ }^{9}$

F. Ferretti, 2019 "Between radical geography and humanism: Anne Buttimer and the International Dialogue Project", Antipode, 2019 early view: https://onlinelibrary.wiley.com/doi/full/10.1111/anti.12536 [author's pre-print version] 
Crucially, at the very beginning of the project, Buttimer synthetized the spirit of the endeavour to the newly appointed collaborator Nordin as follows: 'It is hard to explain it all without drowning you: basically, I am trying to initiate a kind of conscientização ... I try to assemble a number of senior people who would be willing to take a retrospective look at their own experiences.' 10 This shows both the presence of Freire's views from the very beginning of Buttimer's reflection and her very comprehensive views of 'pedagogy', which matched Freire's. In 1979, Buttimer wrote to Bunge that she had started a project in the name of 'Ivan Illich and Paulo Freire', ${ }^{11}$ names that were likely to appeal to her correspondent, given the appraisal of both authors in radical circuits. In 1984, Buttimer discussed Freire's ideas with Ian G. Cook in Liverpool, who was delighted to find such radical content in Buttimer's work:

I was surprised by your reference to Freire and your expressed commitment to work on the street. I have long admired your work ... but had not guessed the depth of your commitment to radical geography ... Personally, I've worked through the U.S.G. in this country but retain a healthy scepticism about 'intellectual' Marxism, finding much of value in structural critique fused with an anarcho-humanist concern for solutions. Perhaps you would like to write something for the new journal which I help co-edit, perhaps on the lines of your commitment to Freire. ${ }^{12}$

In discussion with British 'heretic' geographer Keith Buchanan (Ferretti and Jones 2018) Buttimer argued that the Dialogue Project, for its participants, 'has been a kind of Freire conscientização, ${ }^{13}$. In 1986, she tried unsuccessfully to hold an interview with Umberto Eco, claiming first the Freirean inspiration of her project: 'Since 1978 I have been working on an international "dialogue" project, Freire style, based on autobiographical accounts' ${ }^{14}$ Therefore, Freire is a central reference to understand the radicality of the Dialogue Project.

Though this project did not involve poor people, which indeed constitutes a substantial difference vis-à-vis Freire's approach, Buttimer often called for a more general need for human liberation from oppression that did not depend on people's belonging to a social class, but to the actions of various oppressive institutions. As she claimed in one of her most famous papers: 'At times when Academy, Church, State, Syndicate, or Proletariat has tried to exercise

F. Ferretti, 2019 "Between radical geography and humanism: Anne Buttimer and the International Dialogue Project", Antipode, 2019 early view: https://onlinelibrary.wiley.com/doi/full/10.1111/anti.12536 [author's pre-print version] 
monopoly power over thought and/or life, a humanist protest has appeared' (Buttimer 1990:2). This was the case with the rise of critical and radical geographies in the 1960s and 1970s, which Buttimer defined as an 'emancipatory cry, one seeking freedom from oppression' (Buttimer 1990:2). For Buttimer and Hägerstrand, dialogue was a libertarian practice that could 'counteract fragmentation and lack of mutual understanding' (Buttimer and Hägerstrand 1980:v) between scholars and practitioners and between geographers of different political and epistemological tendencies. This was implicitly exemplified by an alliance forged between 'humanistic' geographer Buttimer and spatial scientist Hägerstrand, who was admittedly convinced by Buttimer to consider new ideas, as the project was 'initially designed by Anne Buttimer' (Buttimer and Hägerstrand 1980:v). Whereas the Dialogue Project was more likely to reach an intellectual elite than the popular classes, some anti-elitist concerns are recognisable in the authors' final calls for valuing 'practical wisdom' rather than specialisation to rediscover 'the development of human qualities other than the purely intellectual and technical' (Buttimer and Hägerstrand 1980:63), marginalised by mainstream academic practices. The fact that scholars and other professionals can be considered on various extents as complicit with the 'oppressive institutions' listed by Buttimer in the quote above, and the lack of explicit political guidance offered by the Dialogue Project, clearly expose some of its limitations. Yet, it is possible to argue that this project's contribution stands rather in the practices that it can still inspire than in its direct outcomes. As I explain in the following section, an important opening of this project was that Buttimer, pioneering the use of devices like videotapes for recording and circulating discussions while showing their material embodiments, anticipated what is called today 'the spirit of collective praxis evident especially in feminist geography' (RoseRedwood et al. 2018, 110)

\section{The archive, North-South networks and transnational feminisms}

After Buttimer's death in July 2017, all of her books and documents were moved to the UCD School of Geography in agreement with her family and in compliance with her Will. At this stage, it is impossible to make full sense of the richness and complexity of these materials, which fill nearly 200 large boxes with books, printouts and numerous folders related to conferences, IGU business, manuscripts, correspondence and work materials. This paper is based on an initial exploration of six boxes containing several dozens of correspondence folders roughly referring to the 1970s and 1980s. Buttimer often kept typewritten accounts of the letters

F. Ferretti, 2019 "Between radical geography and humanism: Anne Buttimer and the International Dialogue Project", Antipode, 2019 early view: https://onlinelibrary.wiley.com/doi/full/10.1111/anti.12536 [author's pre-print version] 
that she sent, enormously facilitating the task of the researcher interested in tracing her work for the Dialogue Project, inspired by 'the need for networking' (Buttimer 1986:98) to realise conscientização practices and to integrate formal outcomes of the project based on tape recordings and in-person meetings. Transcripts of interviews and meetings were printed, and many recordings have been published as online videos after digitizing original tapes under the supervision of the late Buttimer with special attention to interviews held with geographers. However, the interviewees, including politicians and professionals, represented the fields of 'Geography, Planning/Development, Healthcare, Creativity, Enterprise, Intercultural Communication, Philosophy and Science' (Buttimer 1986:24). Her correspondence allows appreciating Buttimer's voluntarist efforts and the challenges she experienced in overcoming various cultural and institutional obstacles highlighted by recent scholarship in geographies of internationalism and transnationalism (Ferretti 2018b; Hodder, Legg and Heffernan 2015). As in other cases, scholarly networking was essential to internationalisation.

The voluntarist (and somehow hard-headed) nature of Buttimer's transnational commitment first emerges in her long correspondence with Hägerstrand, which started in 1971. These letters allow inferring that a decisive part of the voluntarist component underpinning the Dialogue Project was the deep personal friendship between Buttimer and Hägerstrand and that the latter was somehow 'converted' and fascinated by the former's enthusiasm. This led Hägerstrand to rethink some of his previous views of geography and spatial science and in the following years he repeatedly acknowledged Buttimer for his own conscientização, publicly proclaiming that she 'came to Sweden and opened our eyes'. ${ }^{15}$ As a matter of fact, Hägerstrand in 1972 started attempts to secure a scholarship for Buttimer at Lund and wrote to her Head of School in Clark, Saul Cohen, to arrange periods free of teaching for her, offering to send Swedish fellows to work there in exchange. ${ }^{16}$ In the following years, a leitmotiv of exchanges between Buttimer and Hägerstrand represented efforts of the Swedish geographer to "have the money needed for bringing you from Worcester and to Lund and back again' ${ }^{17}$ until Anne's establishment in Sweden when the project was definitively funded. Consistent with Buttimer's humanistic views, humans could rid themselves of borders in this case, enabling a strategic part of her plan: practising internationalism to foster intercultural dialogue and conscientização.

F. Ferretti, 2019 "Between radical geography and humanism: Anne Buttimer and the International Dialogue Project", Antipode, 2019 early view: https://onlinelibrary.wiley.com/doi/full/10.1111/anti.12536 [author's pre-print version] 
Internationalisation (coupled with transnational practices as I explain below) formed part of a broader theoretical framework that included ethical values of tolerance and respect for diversity represented by the Feng-Shui symbol of the Yin/Yang used as the logo of the Dialogue Project, which the promoters defined as a need for an 'understanding of the other' (Buttimer and Hägerstrand 1980:15) and which Buttimer considered as part of her ethics of sharing, as she explained in a letter to Ian Simmons. The "symbol is the YIN/YANG, inviting participants to discover, in their own experiences, the reciprocity of "opposing forces"". ${ }^{18}$ In addition, Buttimer wished to create an International Association for Dialogue whose draft organogram she sketched in a 1982 letter sent to Murdo Morrison, ${ }^{19}$ then employed at Clark as the North American assistant to the Dialogue Project. Significantly, from the first three bases identified by Buttimer one can find Latin America (the other two, of course, being Sweden and the USA), which confirms Buttimer's strong interest in intellectual cooperation with what is today called ‘the Global South' (Ferretti and Jones 2018).

Buttimer's correspondence with Morrison also accounts for material problems that maintaining an international structure implied. These were first economic but also logistical: for instance, recordings of interviews held in different countries highlighted issues of compatibility between different means of reading videotapes, a vanguard technology at the time, hindering the projected circulation of videotapes among universities of different countries for teaching use. ${ }^{20}$ As recent scholarship shows, intellectual life is not straightforwardly international and crossing physical and cultural borders is not always easy (Ferretti 2018b). What is certain is that this was one of the main reasons for Buttimer's involvement with the IGU, where she was the first woman to be appointed President from 2000 to 2004 (and chillingly the only one hitherto).

While her correspondence with former leaders of the IGU Commission of the History of Geography Philippe Pinchemel and Walter Freeman illustrate the primary role that she played in the development of this Commission, ${ }^{21}$ correspondence of the Dialogue Project over the years shows her interest in the IGU as a means to enhance her international outreach and especially in direction of the 'Third World'. For instance, her exchanges with Nigerian geographer Akin Mabogunje show how she arranged an interview that he recorded with Hägerstrand after their meetings at the 1982 Regional IGU Conference in Rio de Janeiro and

F. Ferretti, 2019 "Between radical geography and humanism: Anne Buttimer and the International Dialogue Project", Antipode, 2019 early view: https://onlinelibrary.wiley.com/doi/full/10.1111/anti.12536 [author's pre-print version] 
at the 1984 Geographical International Congress in Paris. ${ }^{22}$ Something similar occurred with Mexican geographer Teresa Gutierrez de MacGregor, whom Buttimer interviewed in Paris taking advantage of the Congress, where eventually MacGregor was appointed vice-president of the IGU. ${ }^{23}$ Several 1982 letters likewise reveal Buttimer's interest in Brazilian geography and her enthusiasm after her first visit to Rio de Janeiro for the 1982 conference, ${ }^{24}$ where she was surprised by the popularity of her own works among local scholars. In Rio Buttimer met her Brazilian correspondents and translators such as Antonio Christofoletti ${ }^{25}$ and arranged a Dialogue interview with Speridião Faissol, a Brazilian geographer also committed to the IGU. ${ }^{26}$

The interviews and meetings recorded account for the diversity of actors and experiences involved in the Dialogue international networks. The first tape produced was recorded at the 1978 inaugural seminary on 'Creativity and Context' in Sigtuna (Sweden), which gathered 35 scholars and professionals to discuss their respective lives and work experiences. In the related tape, Buttimer and Hägerstand facilitate a multilingual discussion between Wolfgang Hartke (Germany), Aadel Brun-Tschudi (Norway), Olavi Granö (Finland) and G.J. van den Berg (Netherlands) on their respective careers. ${ }^{27}$ Diversity emerges in clear contrast between geographers concerned with the imperative of teaching technologies for students' employability, and supporters of social and cultural approaches such as Tschudi. This latter was an exceptional figure and 'late comer' to geography, as she took her degree at a mature age to then start her academic career and considered geography a 'vocation' ${ }^{28}$ However, different approaches converged in concerns expressed by French geographer Jacqueline Beaujeu-Garnier interviewed by Buttimer for exiting the academy's 'ivory tower' ${ }^{29}$ Crucially, in her own interview with Nordin, Buttimer discusses the need to internationalise geography, whose practitioners have been 'the Cinderellas of nation-states' ${ }^{30}$ and whose frames of reference should be removed by practising cosmopolitanism and cross-cultural exchange.

This last statement can be read through the lenses provided by recent literature on transnational feminism, which also allows discussing the problem of Buttimer's commitment to feminism and gender/difference issues, given that she was one of the relatively few female geographers of her generation who reached important institutional recognitions, in her case the IGU Chair. In several writings of (male) humanist geographers (see for instance Ley 1980; Ley and

F. Ferretti, 2019 "Between radical geography and humanism: Anne Buttimer and the International Dialogue Project", Antipode, 2019 early view: https://onlinelibrary.wiley.com/doi/full/10.1111/anti.12536 [author's pre-print version] 
Samuels 1991), one can find a concerning and persistent use of the word 'man' as synonymous with humankind, something clearly problematic from the slightest gender-sensitive perspective. A survey of Buttimer's bibliography demonstrates that she generally employed a different language. Moreover, she often claimed her role in consolidating the IGU Commission on Geography and Gender, and even concluded her mandate at the IGU by acknowledging this Commission, in her foreword to a book on Gendered Cities, for helping in reaching one of her main goals: 'Geography has indeed become more richly peopled' (Buttimer 2004, xviii).

Current definitions of 'transnational feminism' can be outstandingly varied and this notion can be understood both as a 'discourse involving a particular analytic and methodological approach in feminist knowledge production and ... as an empirical referent to feminist cross-border organising, as well as to explore its implications for the study of contemporary transnational feminist networks' (Conway 2017:205-206). Great efforts have been done in mapping transnational women's activist networks (Basu 2000) and, although this was not the case with the Dialogue Project given that most of its participants were men, it is possible to argue that a feminist transnational reading of this experience allows understanding its openings towards ideas of transnational mobilization for justice and equality. First, Buttimer's idea of carrying out dialogue from the level of personal experiences, including intimate memories of home, family and dwelling, chimes with recent feminist questioning of traditional area studies, aiming at 'discerning the drama of difference at the intimate scale of the home and body lends an important optic to the understanding of the scripting of areas' (Oza 2016:841). Second, transnationalism can be an attempt to disrupt 'the distinction between particularistic area studies and research in North American and European contexts' (Pratt et al. 2010:78), in order to challenge statist visions of geography centred on national (and accordingly patriarchal) institutions. Transnationalism is also considered as more adequate to challenge statist frameworks than 'comparative or international analysis, which re-centers the nation as the unit of comparison' (Blackwell, Briggs and Chiu 2015:3) and looks akin to Buttimer's metaphor of Cinderella mentioned above. Third, dialogic praxes are used by feminist authors to foster 'productive tensions' (Peake and Souza 2010:105), that is putting value on difference and heterogeneity of the interlocutors and raising 'issues of positionality, self-reflexivity, and accountability' (Bouchard et al. 2010:221), which was exactly one of Buttimer's targets.

F. Ferretti, 2019 "Between radical geography and humanism: Anne Buttimer and the International Dialogue Project", Antipode, 2019 early view: https://onlinelibrary.wiley.com/doi/full/10.1111/anti.12536 [author's pre-print version] 
Finally, as scholars in transnational feminism suggest, 'worldwide scripts of liberation don't flow necessarily from north to south, but they also flow south back to north, in unexamined ways' (Blackwell, Briggs and Chiu 2015:3). This was the case with Buttimer's Freirean inspiration.

Albeit she never took the label of 'feminist', Buttimer clarified in an interview with Avril Maddrell that she had addressed several matters "which may have seemed out of step with 1970s and 1980s feminism, but arguably [have] more resonance with the more recent...destabilisation of gender' (Maddrell 2009:742). Again, Buttimer's nonconformist attitudes emerged in refusing 'fashionable' labels and easy definitions while remaining engaged with the social problems they raised. In a 1975 letter to Valeria Leach enquiring about feminism, Buttimer explained that she had written an unpublished paper entitled 'Beyond sexist rhetoric' arguing for 'the liberation of the whole person', ${ }^{31}$ a definition that was not necessarily understood in the radical circuit of those years, but which accounted for her commitment to feminism and gender. This paper had to be included in a book edited by Pat Burnett, Women's Role in Changing the Face of the Earth, which was finally not published, but exerted an impact circulating in typewritten form. In her paper, Buttimer argued that: 'We may all have elements of male and female in us and if we inherit a situation of injustice, then we are both impoverished and we should work together in placing the whole human person at the centre of concern. Perhaps this was not what some early feminists wanted to hear, but the paper was very widely circulated' (Maddrell 2009:742). Although an original copy of this chapter was not found in Buttimer's archives hitherto, it is possible to consider these ideas as relevant for later questionings of gender essentialism and binary roles, opening possible research lines on relations between humanism and feminism in geography.

It is possible to argue that Buttimer's special willingness to involve women, scholars from the South and various radicals in her networks, indicates her awareness of these complicated and unexpected flows of liberation. The sources analysed show how Buttimer's networking for the Dialogue Project and for the IGU served as a means to deploy theory-praxis in a Freirean sense by fostering internationalism and transnationalism. In the next session, I discuss how

F. Ferretti, 2019 "Between radical geography and humanism: Anne Buttimer and the International Dialogue Project", Antipode, 2019 early view: https://onlinelibrary.wiley.com/doi/full/10.1111/anti.12536 [author's pre-print version] 
Buttimer's direct engagement with Marxist, feminist and anarchist geographers and with alternative geographical traditions matched this programme.

\section{Dealing with radicals and radical traditions}

Buttimer's doctoral and postdoctoral works on French geography and her fieldwork on Glasgow's working-class neighbourhoods of the late 1960s drew explicitly upon the definition of 'social geography' providing insights unknown to North American geographers and which called the attention of politically engaged scholars. In the 1969 letter quoted in exergue, Marxist geographer David Harvey did not only proclaim after receiving printouts from Buttimer that they were saying the same thing through different theoretical traditions. He also endorsed Buttimer's work as linguistic and cultural transferor. 'You have the big advance over me there and I find myself much indebted to your discussions on the French literature'. ${ }^{32}$ Based at Johns Hopkins University, Harvey welcomed a visit from Anne's to Baltimore in the event that she travelled to the east coast, having 'heard that you might visit Clark sometimes in the near future' ${ }^{33}$ In Clark, Buttimer would be appointed few months later as a postdoctoral fellow and then as a lecturer; this letter from Harvey and the memories that I quote below show that in the early 1970s, 'Sister Social Geography', as someone jokingly called her (Maddrell 2009:743), was already acquainted with the 'Gotha' of 'Radical Geography', then based on the journal Antipode founded in 1969 by one of Buttimer's colleagues at Clark, Richard Peet.

These scholarly networks also included Jim Blaut, who in 1970-71 attended 'a faculty seminar on environmental perception and behaviour' (Buttimer 1980:14). Also a contributor to Antipode (Buttimer 1971), Buttimer witnessed the importance of the journal as 'an organ for the articulation of many other views, particularly Marxist and anarchist ones' (Buttimer 1980:15), accounting for a 'lively debate [which] developed between "our" existentialist vantage point and that of the revolutionary theorists. ... On any debate between intellectual socialists and intellectual existentialists, the latter, it seemed, were inevitably the losers..... As key links between these two stances, Myrna Breitbart and Mick Godkin were especially welcome in 1972 and 1973: for both Dick Peet and for me these two persons played an enormously important role' (Buttimer 1980:15-16). Crucially, this link was social geography and

F. Ferretti, 2019 "Between radical geography and humanism: Anne Buttimer and the International Dialogue Project", Antipode, 2019 early view: https://onlinelibrary.wiley.com/doi/full/10.1111/anti.12536 [author's pre-print version] 
eventually Breitbart's 'fieldwork on anarchist communities in Spain' (Buttimer 1980:16), matching Buttimer's programme.

Buttimer's 1974 Values in Geography has been recently defined as a work seeking dialogue between 'humanism' and radical tendencies, in which she explicitly committed to social justice and criticised the state and the academic establishment (Ferretti and Jones 2018). In commentaries from Edward Soja, Edward Gibson, Yi-Fu Tuan, Blaut and Hägerstrand included in the same volume, Buttimer's work was generally praised with some critiques especially from Blaut, who deemed Buttimer's geography to be too 'moderate' relative to those of three geographers who were politically persecuted at different times and who were ironically among Buttimer's own favourite authors - Reclus, Kropotkin, and more recently Bunge (Blaut 1974). Years after, in a letter to George Carey requesting information on geographical paradigms, Buttimer made a general assessment of that first decade of 'radical' geography, arguing that: "As far as critical (Marxist or other) thought, I consider Bunge as pioneer, and then David Harvey. There are clever epigons, of course, and prolific [authors] among the critical writers, but a lot of it is piracy and chatter' ${ }^{34}$ What is significant is Buttimer's direct engagement and personal acquaintance with many of these 'critics' starting from the already often-mentioned Bunge.

William Wheeler Bunge (1928-2013) was an incredibly influential figure in the development of quantitative geography and spatial science after the publication of his 1962 Theoretical Geography and in the critical and radical turn pioneered by his 1971 work Fitzgerald, Geography of a Revolution following the Detroit expeditions discussed above (Barnes and Heynen 2011). It is worth noting that, before that 'humanistic geographies' became a current definition, Bunge defined Fitzgerald as a 'humanist geography' (Bunge 1971:frontispice). Yet he was academically and politically marginalised his entire life and never managed to secure a tenured university position (Barnes 2017). While according to Merrifield, Bunge remained a member of 'the spatial science brigade' (Merrifield 1995:59) still when he conducted social fieldwork in the Black neighbourhood of Fitzgerald, Bunge's correspondence with his historical enemy Richard Hartshorne (1899-1992), analysed by Barnes, accounts for some of Bunge's steps in the direction of 'idiographic' approaches. Barnes's commentaries on letters

F. Ferretti, 2019 "Between radical geography and humanism: Anne Buttimer and the International Dialogue Project", Antipode, 2019 early view: https://onlinelibrary.wiley.com/doi/full/10.1111/anti.12536 [author's pre-print version] 
exchanged between the 'odd couple' of Bunge and Hartshorne can be applied to the equally odd correspondence between Bunge and Buttimer, which likewise allows for the appreciation of 'what is brought to [scholars'] frontstage academic work, but usually concealed, such as gender, emotional baggage, biography, and past relationship ... giving a different grain to the history of geography, making its stakes more immediate, vital and gripping' (Barnes 2016:459).

Bunge's first letter stored in Buttimer's archives opens by stating: 'Dear Sister, you are one of those people who really annoy me. It is as if you have cornered morality ${ }^{35}$ as a response to Values. It ends by asking Buttimer to order a book on The Canadian Alternative, which Bunge was preparing. Buttimer's response, which followed a phone call between the two geographers, was firm in content but cordial in tone. She first claimed that she had no intention to 'moralise' anyone: 'My aim is to call people's consciences to life rather than steer them into a particular moral line ... I just want each of us to try and examine the consistency between what we say and what we do, between who we are and what is expected of us in our different roles. The revolution I would like to see com[ing] about in society generally may not differ enormously from the one you preach about ... In my view, the one fundamental and pervasive characteristic of a revolutionised social order would be one in which a caring and loving attitude among individuals would be normal and not exceptional.' ${ }^{36}$ Again, Buttimer maintained a critical distance from the most 'fashionable' revolutionary proclaims but agreed on the need for a 'social revolution' that should include 'care' and 'love' not unlike Freire or the anarchist tradition (Malatesta 2014).

The conclusions of this letter account for Buttimer's respect for Bunge's work and person. 'Of course, I shall order your monograph - I keep a complete collection of your writings. ... Good luck, and some time go in your room, close the door, shut off the radio, and close your eyes and ask yourself some of the simple-minded questions I have just posed to you. I would be fascinated to hear what comes to your mind and heart'. ${ }^{37}$ This does not merely reflect formal kindness, as in the following years Buttimer proved to be keen to help Bunge in his attempts to find a Swedish publisher for the book Geography, Innocent Science, ${ }^{38}$ which remained unpublished due to disagreements between Bunge and his co-author William Warntz

F. Ferretti, 2019 "Between radical geography and humanism: Anne Buttimer and the International Dialogue Project", Antipode, 2019 early view: https://onlinelibrary.wiley.com/doi/full/10.1111/anti.12536 [author's pre-print version] 
(Bergmann and Morrill 2018). Bunge also needed money for his family in Canada and did not hesitate to ask Buttimer if she could find paid work for him. ${ }^{39}$ He also sent several pages of commentaries on his life and ideas, even sharing with his correspondent unsurprising commentaries about their colleagues: 'I just don't like most geographers' ${ }^{40}$ Buttimer's 'humane' approach was finally acknowledged by Bunge who wrote that: 'You make me feel real[ly] good, and that is nice and also rather rare' ${ }^{41}$ Friendly tones of this correspondence are confirmed by Buttimer's letter announcing her marriage. ${ }^{42}$ An incredible document acting as Bunge's family autobiography arranged in a Dadaist manner titled Donia's Garden and apparently never published starts with a sort of dedication to 'Anne Buttimer, Catholic [who] is to meet here in but six days and her trip inspired me to finally get this material written over many years into this almost finished shape' ${ }^{43}$ While these materials will require further study, the relationship between Buttimer and Bunge exemplifies mutual recognition between Buttimer's humanism and social Catholicism and many geographers' Marxist or anarchist radicalism.

Recent scholarship has discussed correspondence between Buttimer and two radical geographers committed to 'Third World' issues, the Brazilian Milton Santos and the British Keith Buchanan (Ferretti and Jones 2018; Power and Sidaway 2004). New materials emerging from the archive confirm arguments advanced by these works on Buttimer's special interest in the 'South' associated with her special connection to scholars extraneous to all orthodoxies including 'radical' orthodoxies. Letters sent by Santos from Columbia University, where he worked in 1976-77, account for their shared critiques of geography. There, Buttimer again acted as a confident to her correspondents' political and scholarly disappointment and in this case to a geographer who was living a painful existence of exile due to political persecution in his country (Ferretti 2018b). 'I have read a lot, thought a lot, and taken a lot of notes, but what geographers do nowadays is in general so far from the values ... that sometimes I feel as if I was insulting people. I have difficulty understanding why journals like Annals shelter so many unuseful [sic] works. The fact that all these journals are alive and these papers praised gives me the feeling that I am in the wrong world' ${ }^{44}$ In Buttimer's correspondence with Buchanan, a certain air of deception is expressed by both scholars. While Buchanan laments being temporarily 'unemployed and outside the university system', ${ }^{45}$ Buttimer notes on her part being

F. Ferretti, 2019 "Between radical geography and humanism: Anne Buttimer and the International Dialogue Project", Antipode, 2019 early view: https://onlinelibrary.wiley.com/doi/full/10.1111/anti.12536 [author's pre-print version] 
"tired of being considered as a "missionary" or a "Cassandra" or as a "conscience" 46 and acknowledges Buchanan for taking her questions seriously. Buttimer's proposal to Buchanan (who was Welsh) is in line with their shared sense of anti-colonialism: a collective book on Geography and the Celtic Fringe (then not realised) collecting autobiographies of geographers from Wales, Ireland and Scotland, where she argued that 'most interesting people [who] had something to do with geography ${ }^{47}$ had origins, including 'E.E. Evans, E. Bowen, C. Darby, E. Jones, R.O. Buchanan, W. Watson and many others' ${ }^{48}$ Again, everyone and everything at the 'margins' attracted Buttimer.

As a historian of geography, Buttimer engaged with alternative and radical geographical traditions. A telling anecdote concerns her correspondence with the young David $\mathrm{N}$. Livingstone, then a PhD student in Belfast, whom Buttimer advised to publish in Antipode or Hérodote rather than 'bother to knock on the door of establishment journals' ${ }^{49}$ Livingstone is a widely internationally renowned scholar, but he is not considered to be one of the most engaged 'radicals': therefore, this drive to suggest publishing in radical journals came accordingly from Buttimer's interests rather than from those of her eventual interlocutor. Buttimer was also invited by David Stoddart to contribute to the collective book Geography, Ideology and Social Concern, ${ }^{50}$ a work that called scholarly attention to anarchist traditions of geography and especially through chapters on Reclus, Kropotkin and Patrick Geddes respectively written by Gary Dunbar, Myrna Breitbart and B.T. Robson. Stoddart expressed views on the history of geography akin to what Clarence Glacken, interviewed by Allan Pred for the Dialogue Project, called 'humility', ${ }^{51}$ which involves avoiding contemporary scholars' presumptions of having invented everything. Eventually, Stoddart expressed interest in the fact that many contemporary 'post-positivist concerns were shared by geographers 50-100 years ago', ${ }^{52}$ focusing on the possible continuity of 'old' theories in geography. In addressing one of the most widely studied cases in this continuity, that of early anarchist geographers, Buttimer enjoyed comparative advantages as highlighted by Harvey: her linguistic skills and her familiarity with the history of French geography.

In 1965, Buttimer lived in France for several months to connect with a number of French geographers. ${ }^{53}$ In 1966, she received a list of French books to read including works of Jean

F. Ferretti, 2019 "Between radical geography and humanism: Anne Buttimer and the International Dialogue Project", Antipode, 2019 early view: https://onlinelibrary.wiley.com/doi/full/10.1111/anti.12536 [author's pre-print version] 
Brunhes, Albert Demangeon, Lucien Febvre, Lucien Gallois, Elisée Reclus, Paul Vidal de la Blache. ${ }^{54}$ It is not surprising that a major specialist of Reclus, Gary Dunbar (1931-2015), repeatedly requested Buttimer's expertise on the anarchist geographer, having been impressed by her works on French geography. ${ }^{55}$ Their correspondence continued from 1971 to $2005 .{ }^{56} \mathrm{In}$ 1974, they discussed Dunbar's meticulous investigation tracing the earliest occurrences of the term géographie sociale in the history of French geography (Dunbar 1977). ${ }^{57}$ While Dunbar showed that this definition was first used in reviews of Reclus's works, though more recent studies suggest that the initiator was Kropotkin (Ferretti 2018a), it is clear that Buttimer was especially well placed to offer her expertise. In the following months Dunbar also enquired with 'William Pattison, Brian Goodey, Emrys Jones, David Harvey and Vincent Berdoulay'58 to ensure that he was not overlooking any of Reclus's materials in this work. This illustrates the extent of Buttimer's reputation in this field, which is also apparent in her correspondence with Kenneth Olwig, author of a paper on Reclus and Perkins Marsh and keen to receive advice from Buttimer, who directed him to Dunbar and Breitbart while also offering a copy of Breitbart's dissertation, which she had brought with her from Sweden. ${ }^{59}$

As a contribution to the 1970 s rediscovery of anarchist approaches, which culminated with the publication of an Antipode special issue in 1978 (Breitbart 1978b), Buttimer co-supervised (with Richard Peet) Myrna Breitbart's work in Clark, dealing with the anarchist communities of 1936-39 Spain inspired by Reclus and Kropotkin's notions of decentralisation (Breitbart 1978a). Correspondence shows that it was Buttimer to put Breitbart in touch with Stoddart for Geography, Ideology and Social Concern. ${ }^{60}$ At the same time, Buttimer suggested Breitbart to publish with 'an emphasis on practice because you have already written and published plenty on old Master K[ropotkin]. ${ }^{61}$ This irony did not mean that Buttimer overlooked the importance of Kropotkin's legacy, as she mentioned several times that the Anarchist Prince was one of her favourite authors, for instance discussing a paper by John Dickenson on Henry Walter Bates (1825-1892), one of Kropotkin's acquaintances at the Royal Geographical Society (Dickenson 1992; Kearns 2004). 'I was particularly intrigued by the connection you drew between Bates and Kropotkin, the latter being one of my real favourites in the history of geographic thought' ${ }^{62}$

F. Ferretti, 2019 "Between radical geography and humanism: Anne Buttimer and the International Dialogue Project", Antipode, 2019 early view: https://onlinelibrary.wiley.com/doi/full/10.1111/anti.12536 [author's pre-print version] 
Finally, when Buttimer received a letter from Nicholas Helburn asking her opinion on a potential link between 'humanistic' notions of dwelling and nationalism (or patriotism), she replied arguing that her opinion on this matter was contained in a long quote from Kropotkin's 'What geography ought to be' (1885): 'Geography ... must teach us that we are all brother, whatever our nationality ... dissipating prejudice and creating other feelings more worthy of humanity... Only small parts of each nation are interested in maintaining national hatred and jealousies'. ${ }^{63}$ This definitively demonstrates that the critiques mentioned above of 'dwelling' as a somehow conservative concept cannot apply to Buttimer's case. Buttimer's engagement with radical geographers and traditions discussed in this section indicates that her humanistic approach was not less radical in its intellectual critique of the establishment albeit with its peculiar language. This is not surprising when one considers Buttimer's engagement with Freire and her familiarity with Kropotkin and Reclus.

\section{Conclusion}

Addressing archives and concrete scholars' practices through biographical approaches and contextual readings that consider concrete life trajectories and daily practices alongside theories proves to be indispensable for analysing the production and transnational circulation of scholarly knowledge. Albeit the Dialogue Project was characterised by limits in its effective inclusiveness in terms of class, gender or ethnicity as discussed above, dialogical practices are still considered as a necessary device for engaged geographical scholarship and can still find outstanding elements of interest in this experience. Buttimer's work serves as an example of merging theories and praxes following Freire, one which allows appreciating the centrality of dialogue as both a notion and a concrete practice.

The Dialogue Project had a profound impact on subsequent scholarship addressing the relation between geography, feminism and autobiography. It is the case with work by Pamela Moss, matching some of the 'humanistic' geographers' views on the importance of daily life, especially in her discussion on the role that her own life experiences played in developing a scholarly interest for 'reintroduc[ing] autobiography into geography' (Moss 2001:4). For Moss, autobiography has been used in several ways in geography, by applying it to scholars themselves or to fieldwork practices, for instance in the use of interviews. Among the

F. Ferretti, 2019 "Between radical geography and humanism: Anne Buttimer and the International Dialogue Project", Antipode, 2019 early view: https://onlinelibrary.wiley.com/doi/full/10.1111/anti.12536 [author's pre-print version] 
references mobilised by the author, the Dialogue Project is mentioned among the principal inspirations (Moss 2001:7) and associated with feminism, eventually through the idea that the personal spheres of individuals matter to scholarship. One might argue that this notion of 'personal is scholarly' parallels the classical feminist claim that 'personal is political' in challenging conservative views of 'objective' and disembodied knowledge. In a later book on the writing of intimacy in feminist geography edited by Moss and by Courtney Donovan, the authors argue that, within the "intimate turn in geography ... autobiographical writers have adroitly drawn out the relationship between the singularity of individual experience and the wider processes through which individuals are embedded' (Donovan and Moss 2017:4). While literature on intimacy and emotional geographies goes well beyond autobiography, it is possible to argue that autobiography and dialogue provided ground for breaking the frontiers of geography and of scholarship itself, fostering socially engaged knowledge. Although Buttimer is not quoted in this last book, autobiography contributed to pave the way for these strands of literature by exposing the need for considering praxes alongside theories. This opens the way for new studies reconsidering experiences like Buttimer's, whose huge archive still needs to be fully explored in this sense.

Conversely, recent geographical scholarship has discussed openings and limitations of dialogue practices, which are considered as essential devices for scholarly engagement although, in the era of digital social networks, they are complicated by heterogeneous arrays of uses and misuses of dialogical praxes. As observed by the editors of a recent Dialogues in Human Geography special issue on these matters, 'dialogue can also be weaponized and used as a tactic of harassment' (Rose-Redwood et al. 2018:112) especially in social media. While this raises contemporary issues on cyber-harassment and cyber-bullying, joining discussions on what should be the academic tolerance towards racist, sexist or discriminatory statements released by political groups disgracefully active on some campuses, what recalls the Dialogue Project in contemporary scholarship is the current understanding of "scholarly dialogue as a form of embodied action, to envision a critically affirmative politics of dialogical encounter ... not confined to the textuality of the written word alone' (Rose-Redwood et al. 2018:112-113). The Dialogue Project can provide insights for current debates on the limits to dialogue, being the example of an interdisciplinary and interprofessional approach, targeting communication

F. Ferretti, 2019 "Between radical geography and humanism: Anne Buttimer and the International Dialogue Project", Antipode, 2019 early view: https://onlinelibrary.wiley.com/doi/full/10.1111/anti.12536 [author's pre-print version] 
among scholars and non-scholars in different sectors, including administration, planning and international cooperation (Buttimer 1984). Assuming current claims that dialogue is not a notion to be taken for granted, but a concrete praxis to be daily constructed in different contexts, it is possible to state the urgency of 'a renewed practice of critically affirmative dialogue' (Rose-Redwood et al. 2018:118) to face current scholarly and societal challenges. In the era of digital possibilities paralleled by the concurrent raising of nationalisms and ethnical supremacism, ideas of face-to-face communication driven by empathy and 'catalysis' as humane practices intended to cope with differences remain an inspiration for enhancing contemporary radical agendas.

Additionally, conscientização still appears to be urgently needed in the academic world and in the global political situation of recent years (A collective of anarchist geographers, 2017). In a world increasingly filled with barriers of all kinds, consciousness, cross-cultural communication and the practice of internationalism can still serve as powerful tools in the hands of scholars committed to changing society and to challenging racisms and nationalisms from a plurality of political and theoretical approaches, such as those used in the Dialogue Project. This can contribute to contemporary debates in feminism and transnational studies, where authors still face the challenge of using 'quantitative methods in a non-positivist way' (Peake and Souza 2010:105), that is building bridges between different critical approaches to geography.

While Buttimer's interest for radical geographies in the 1970s and 1980s could be hardly generalised to all the authors and works broadly labelled as 'humanistic geographies', the documents analysed above show the proximity of the respective circuits, allowing to get rid of rigid classificatory categories. This is one of this paper's key contributions for future works on radical histories and theories: we should stop thinking that, if an author does not explicitly declare her/himself as Marxist, feminist or anarchist, she/he cannot be a radical critic of disciplinary conformism or social/political conservatism. While Buttimer engaged with anarchism and radicalism without manifestly being a radical or an anarchist, promoters of critical and radical agendas today should reflect on her open-mindedness, intellectual curiosity, scholarly and social commitment, and lived transnationalism and multilingualism.

F. Ferretti, 2019 "Between radical geography and humanism: Anne Buttimer and the International Dialogue Project", Antipode, 2019 early view: https://onlinelibrary.wiley.com/doi/full/10.1111/anti.12536 [author's pre-print version] 


\section{Acknowledgements}

I first acknowledge the family of Anne Buttimer, and especially Andreas Buttimer, for their kindness and availability in the process of transferring this precious collection to UCD. Special thanks to the colleagues who work with me in this endeavour: Arlene Crampsie, Alun Jones and Francesco Ventura. Many colleagues provided great information and anecdotes on Anne and her international networks and I could not list all of them there, but I shall mention Christian Abrahamsson, Gunnar Olsson, Trevor Barnes and Franco Farinelli. I also acknowledge the attendants to the conferences where I presented and discussed some aspects of Buttimer's archives in 2018, that is the $50^{\text {th }}$ Conference of Irish Geographers in Maynooth, the Symposium of the IGU Commission History of Geography in Quebec City and the $5^{\text {th }}$ Brazilian Conference on the History of Geography in Viçosa (MG). Finally, great thanks to the three anonymous referees for Antipode for their invaluable suggestions and to the editor, Kiran Asher, for her help and great bibliographical insights.

\footnotetext{
${ }^{1}$ University College Dublin, School of Geography, Anne Buttimer's Archives (hereafter DBA) [provisional inventory], Folder South America, Buttimer to Faissol, 9 June 1982.

2 DBA, Canada Folder, Ley to Buttimer, 2 April 1976.

${ }^{3}$ DBA, Canada Folder, Ley to Buttimer, 2 April 1976.

${ }^{4}$ DBA, Seamon Folder, Seamon to Buttimer, 12 November 1991.

${ }^{5}$ DBA, Seamon Folder, Seamon to Buttimer, 17 February 1993.

${ }^{6}$ DBA, Sweden Folder, Seamon to Buttimer, 1 October 1979.

7 Antipode Foundation, The Union of Socialist Geographers Newsletter, 1975-1983 https://antipodefoundation.org/2017/06/28/usg-newsletter-archive/

${ }^{8}$ UCD School of Geography, Life Experience as catalyst for cross-disciplinary communication (hereafter DIAUCD), G10, Buttimer interviewed by Nordin, 1979 https://www.youtube.com/watch? $\mathrm{v}=\mathrm{yN}-$ LJIiOBeE\&feature $=$ youtu.be

9 DIA-UCD, G10 Buttimer interviewed by Nordin, 1979 https://www.youtube.com/watch? $\mathrm{v}=\mathrm{yN}-$ LJliOBeE\&feature $=$ youtu.be

${ }^{10}$ DBA, Sweden, Buttimer to Norden, 26 May 1978.

11 DBA, USA 1978-1995, Buttimer to Bunge, 16 February 1979.

12 DBA, England-Scotland 1966-1988, Cook to Buttimer, 9 February 1984.

${ }^{13}$ DBA, Folder Buchanan, A. Buttimer to K. Buchanan, 19 April, 1984

${ }^{14}$ DBA, Sweden, Buttimer to Eco, 15 July 1986.

15 DIA-UCD, G09 Hägerstrand interviewed by 1980 , https://www.youtube.com/watch?v=bLWzyCFr4yU

${ }^{16}$ DBA, Hägerstrand Folders, Hägerstrand to Cohen, 25 September 1972.

${ }^{17}$ DBA, Hägerstrand Folders, Hägerstrand to Buttimer, 25 April 1975.

18 DBA, England-Scotland 1966-1988, Buttimer to Simmons, 27 June 1982.

${ }^{19}$ DBA, DIA Correspondence, Buttimer to Morrison, 27 June 1982

${ }^{20}$ DBA, Dialogue Correspondence Folder.

${ }^{21}$ DBA, France Folder; Freeman Folder.
}

F. Ferretti, 2019 "Between radical geography and humanism: Anne Buttimer and the International Dialogue Project", Antipode, 2019 early view: https://onlinelibrary.wiley.com/doi/full/10.1111/anti.12536 [author's pre-print version] 
${ }^{22}$ DBA, South America, Mabogunje to Buttimer, 23 August 1982; Paris 84 Folder, Mabogunje to Buttimer, 12 October 1984; Buttimer to Mabogunje, 7 November 1984.

${ }^{23}$ DBA, Folder Paris 1984, Gutierrez MacGregor to Buttimer, 30 July 1984.

${ }^{24}$ DBA, Dialogue Correspondence, Buttimer to Morrison, 20 August 1982.

${ }^{25}$ DBA, South America, Christofoletti to Buttimer, 12 April 1980.

${ }^{26}$ DBA, South America, Faissol to Buttimer, 13 September 1982.

27 DIA-UCD, G01, Sigtuna: Cross-cultural perspectives on Geography, 1978 https://www.youtube.com/watch?v=BQWD2TJ7_jA\&feature=youtu.be

28 DIA-UCD, G08, Brun-Tschudi interviewed by Nordin, 1979,

https://www.youtube.com/watch? v=LQR0yO794p0\&feature=youtu.be

${ }_{29}$ DIA-UCD, G21 Beaujeu-Garnier interviewed by Buttimer, 1981, https://www.youtube.com/watch? $\mathrm{v}=\mathrm{oB}-$ kn14u4Ac\&feature $=$ youtu.be

30 DIA-UCD, G10, Buttimer interviewed by Nordin, 1979 https://www.youtube.com/watch? $\mathrm{v}=\mathrm{yN}$ LJliOBeE\&feature $=$ youtu.be

${ }^{31}$ DBA, USA 1967-1977, Buttimer to Leach, 24 October 1975.

32 DBA, USA 1967-1977, Harvey to Buttimer, 20 December 1969.

${ }^{33}$ DBA, USA 1967-1977, Harvey to Buttimer, 20 December 1969.

${ }^{34}$ DBA, USA 1978-1995, Buttimer to Carey, 12 May 1982.

${ }^{35}$ DBA, USA 1967-1977, Bunge to Buttimer [1975].

${ }^{36}$ DBA, USA 1967-1977, Buttimer to Bunge, 10 December 1975.

${ }^{37}$ DBA, USA 1967-1977, Buttimer to Bunge, 10 December 1975.

${ }^{38}$ DBA, USA 1978-1995, Bunge to Buttimer, 17 November 1978.

${ }^{39}$ DBA, USA 1978-1995, Bunge to Buttimer, 25 December 1978.

${ }^{40}$ DBA, Values Folder, Bunge to Buttimer, no date

${ }^{41}$ DBA, USA 1978-1995, Bunge to Buttimer, 23 January 1979.

${ }^{42}$ DBA, USA 1978-1995, Buttimer to Bunge, 2 March 1979.

${ }^{43}$ DBA, Bunge Folder, Donia's Garden, November 21, 1999.

${ }^{44}$ DBA, USA 1967-1977, Santos to Buttimer, 24 September 1976.

${ }^{45}$ DBA, England-Scotland 1966-1988, Buchanan to Buttimer, 22 January 1978.

${ }^{46}$ DBA, England-Scotland 1966-1988, Buttimer to Buchanan, 8 March 1978.

${ }^{47}$ DBA, England-Scotland 1966-1988, Buttimer to Buchanan, 18 September 1978.

${ }^{48}$ DBA, England-Scotland 1966-1988, Buttimer to Buchanan, 18 September 1978

${ }^{49}$ DBA, England-Scotland 1966-1988, Buttimer to Livingstone, 2 April 1981.

${ }^{50}$ DBA, England-Scotland 1966-1988, Stoddart to Buttimer, 20 January 1978.

51 DIA-UCD, G15, Interview with Clarence Glacken, 1980,

https://www.youtube.com/watch? $v=i z Z 2 \mathrm{mbXsw} 94 \&$ feature=youtu.be

${ }^{52}$ DBA, England-Scotland 1966-1988, Stoddart to Buttimer, 21 October 1977.

${ }^{53}$ DBA, Box 102 [provisional inventory], Sister Mary Annette, United States.

${ }^{54}$ DBA, England-Scotland 1966-1988, Smith (RGS Map Room) to Buttimer, 29 April 1966.

${ }^{55}$ DBA, USA 1967-1977, Dunbar to Buttimer, 11 October 1971.

${ }^{56}$ DBA, Reclus 2005 Folder.

${ }^{57}$ DBA, USA 1967-1977, Dunbar to Buttimer, 14 June 1974.

${ }^{58}$ DBA, USA 1967-1977, Dunbar to Buttimer, 30 June 1975.

${ }^{59}$ DBA, Denmark, Buttimer to Olwig, 13 February 1979.

${ }^{60}$ DBA, USA 1978-1995, Buttimer to Breitbart, 4 September 1981.

${ }^{61}$ DBA, USA 1978-1995, Buttimer to Breitbart, 19 September 1981.

${ }^{62}$ DBA, England-Scotland 1966-1988, Buttimer to Dickenson, 6 February 1988.

${ }^{63}$ DBA, USA 1978-1995, Buttimer to Helburn, 13 February 1986.

\section{References}

Academia Europaea (2017) Homage to Anne Buttimer (1938-2017).

https://www.youtube.com/watch?v=fEzfKsFvNtU

F. Ferretti, 2019 "Between radical geography and humanism: Anne Buttimer and the International Dialogue Project", Antipode, 2019 early view: https://onlinelibrary.wiley.com/doi/full/10.1111/anti.12536 [author's pre-print version] 
A collective of anarchist geographers (2017) Anarchism and electoral democracy in a turbulent moment. ACME 16(4): http://www.acme-journal.org/index.php/acme/article/view/1571

Adams PC, Hoelscher S and Till KE (eds.) (2001) Textures of Place: Exploring Humanist Geographies. Minneapolis: University of Minnesota Press.

Aronowitz S (1993) Paulo Freire's democratic humanism. In P McLaren and P Leonard (eds) Paulo Freire, a critical encounter (pp 8-24). London/New York: Routledge.

Barnes TJ (2009) 'Not only ... but also': Quantitative and critical geography. The Professional Geographer 61(3):292-300.

Barnes TJ (2016,) The odd couple: Richard Hartshorne and William Bunge. The Canadian Geographer/Le Géographe canadien 60(4):458-465.

Barnes TJ (2017) A marginal man and his central contributions: The creative spaces of William ('Wild Bill') Bunge and American geography. Environment and Planning A, Online First https://doi.org/10.1177/0308518X17707524

Barnes TJ, Heynen N, Merrifield A and Mountz A (2011) Classics in human geography revisited: William Bunge's (1971) Fitzgerald: Geography of a revolution. Progress in Human Geography 35(3):712-20

Basu A (2000) Globalization of the local/Localization of the global: Mapping transnational women's movements. Meridians 1(1):68-84.

Bergmann L and Morrill R (2018) William Wheeler Bunge: Radical Geographer (1928-2013). Annals of the American Association of Geographers 108(1):291-300.

Blackwell M, Briggs L and Chiu M (2015) Transnational feminisms roundtable frontiers. A Journal of Women Studies 36(3):1-24.

Blaut J (1974) [Commentaries to Values in Geography]. In A Buttimer Values in Geography (pp. 44-45). Washington: AAG Commission on College Geography.

Bouchard D et al. (2010) Continuing conversations. In Lock A and Nagar R (Eds.) Critical Transnational Feminist Praxis. New York, SUNY Press:206-218.

Breitbart MM (1978a) The Theory and Practice of Anarchist Decentralism in Spain, 19361939 (PhD Dissertation). Worcester: Clark University.

Breitbart MM (1978b) Introduction. Antipode 10-11(3-1):1-5.

Brunetto G (2010) Paulo Freire e o humanismo anarquista [Blog Paper]: http://www.giancarlabrunetto.com/PauloFreireeohumanismoanarquista.pdf

F. Ferretti, 2019 "Between radical geography and humanism: Anne Buttimer and the International Dialogue Project", Antipode, 2019 early view: https://onlinelibrary.wiley.com/doi/full/10.1111/anti.12536 [author's pre-print version] 
Bunge W (1971) Fitzgerald: Geography of a Revolution. Cambridge/MA: Schenkman Publishing Company.

Buttimer A (1971) Health and welfare: Whose responsibility? Antipode 3(1):31-45.

Buttimer A (1974) Values in Geography. Washington: AAG Commission on College Geography.

Buttimer A (1980) Introduction. In A Buttimer and D Seamon (eds) The Human Experience of Place and Space (pp. 13-18). London: Croom Helm Publishers.

Buttimer A (1986). Life Experience as Catalyst for Disciplinary Communication: Adventures in Dialogue 1977-1985. Lund: DIA.

Buttimer A (1990) Geography, humanism, and global concern. Annals of the Association of American Geographers 80(1):5-34.

Buttimer A (1993) Geography and the Human Spirit. Baltimore and London: John Hopkins University Press.

Buttimer A (2004). Preface. In G Cortesi (ed.) Gendered Cities: Identities, Activities, Networks (pp. xxvii-Xxviii). Rome: SGI/IGU.

Buttimer A and Hägerstrand T (1980) Invitation to Dialogue. Lund: DIA.

Carpenter E (ed) (1897) Humane Science Lectures. London: G. Bell \& Sons.

Clout H (2017) Anne Buttimer 31 October 1938 - 15 July 2017. The Geographical Journal 183(4):455-456.

Codello F (2005) La buona educazione: esperienze libertarie e teorie anarchiche in Europa da Godwin a Neill. Milano: Angeli.

Conway JM (2017) Troubling transnational feminism(s): Theorising activist praxis. Feminist Theory 18(2):205-227

Craggs R. and Wintle C (eds) (2016) Cultures of decolonisation, transnational productions and practices, 1945-70. Manchester: Manchester University Press.

Cresswell T 2013 Geographic Thought: A Critical Introduction. Chichester: Wiley-Blackwell. Dickenson J (1992) The naturalist on the River Amazons and a wider world: reflections on the centenary of Henry Walter Bates. The Geographical Journal 158(2):207-214.

Donovan C and P Moss (2017) Muddling intimacy methodologically. In P Moss and C Donovan (eds.) Writing Intimacy into Feminist Geography (pp. 3-30). London and New York: Routledge.

F. Ferretti, 2019 "Between radical geography and humanism: Anne Buttimer and the International Dialogue Project", Antipode, 2019 early view: https://onlinelibrary.wiley.com/doi/full/10.1111/anti.12536 [author's pre-print version] 
Dunbar GS (1977) Some early occurrences of the term 'social geography'. Scottish Geographical Magazine 93:15-20.

Featherstone D (2015) Maritime labour and subaltern geographies of internationalism: Black internationalist seafarers' organising in the interwar period. Political Geography 49:7-16

Ferretti F (2016) Organisation and formal activism: insights from the anarchist tradition. International Journal of Sociology and Social Policy 36(11-12):726-740

Ferretti F (2018a) Anarchy and Geography. Reclus and Kropotkin in the UK. Abingdon: Routledge.

Ferretti F (2018b) Geographies of internationalism: radical development and critical geopolitics from the Northeast of Brazil. Political Geography 63:10-19.

Ferretti F and Viotto Pedrosa B (2018) Inventing critical development: a Brazilian geographer and his Northern networks. Transactions of the Institute of the British Geographers early view https://onlinelibrary.wiley.com/doi/full/10.1111/tran.12241

Ferretti F and Jones A (2018) Anne Buttimer. 1938-2017. Geographers. Biobibliographical Studies 37:13-40.

Freire P (2000) Pedagogy of the Oppressed, 30 ${ }^{\text {th }}$ Anniversary Edition. London/New York: Continuum.

Heyman R (2007) "Who's going to man the factories and be the sexual slaves if we all get PhDs?" Democratizing knowledge production, pedagogy, and the Detroit Geographical Expedition and Institute. Antipode 39(1):99-120.

Heynen N (2013) Marginalia of a revolution: naming popular ethnography through William W. Bunge's Fitzgerald, Social and Cultural Geography 14(7):744-751

Heynen N, Kent A, McKittrick K, Gidwani V, Larner W (2017) Neil Smith's long revolutionary imperative. Antipode 49(1):5-18.

Horvath J (2016) Pedagogy in geographical expeditions: Detroit and East Lansing. In S Springer, R White, M Lopes de Souza (eds). The Radicalisation of Pedagogy. Anarchism, Geography and the Spirit of Revolt (pp. 101-124). New York: Rowman \& Littlefield.

Jones M (2019) Anne Buttimer's The Practice of Geography: Approaching the history of geography through autobiography Geografiska Annaler: Series B, Human Geography early view: https://www.tandfonline.com/doi/abs/10.1080/04353684.2018.1544468

Kearns G (2004) The Political Pivot of Geography. The Geographical Journal 170:337-346.

F. Ferretti, 2019 "Between radical geography and humanism: Anne Buttimer and the International Dialogue Project", Antipode, 2019 early view: https://onlinelibrary.wiley.com/doi/full/10.1111/anti.12536 [author's pre-print version] 
Kropotkin P (1885) What geography ought to be. The Nineteenth Century 18:940-956.

Ley D (1980) Geography without Man: A Humanistic Critique. University of Oxford: Research Paper 24.

Ley D and Samuels M (eds) (1978) Humanistic Geography, Prospects and Problems. London: Croom Helm.

Maddrell A (2009) An interview with Anne Buttimer: an autobiographical window on geographical thought and practice 1965-2005. Gender, Place \& Culture 16(6):741-765.

Malatesta E (2014) An Errico Malatesta Reader. London: AK Press [ed. by Davide Turcato]. McCormack DP (2017) The circumstances of post-phenomenological life worlds. Transactions of the Institute of British Geographers 42(1):2-13.

McLaren P (2000) Che Guevara, Paulo Freire, and the pedagogy of revolution. London: Rowman \& Littlefield.

Melgaço L (2017) Thinking outside the bubble of the Global North: introducing Milton Santos and 'the active role of geography', Antipode 49(4):946-951.

Melgaço L and Prouse C (eds) (2017) Milton Santos: Pioneer in Geography. London: Springer. Merrifield A (1995) Situated knowledge trough exploration: reflections on Bunge's geographical expeditions. Antipode 27(1):49-70.

Mitchell D (2000) Cultural geography. Oxford: Blackwell.

Mitchell D (2014) Neil Smith, 1954-2012: Marxist Geographer. Annals of the Association of American Geographers 104(1):215-222.

Moss P (2001) Writing one's life. In P Moss (ed.) Placing Autobiography in Geography (pp. 1-7). Syracuse: Syracuse University Press.

Oza R (2016) The entanglements of transnational feminism and area studies. Environment and Planning D: Society and Space 34(5):836-842.

Peake L and Souza K (2010) Feminist academic and activist praxis in service of the transnational. In Lock A and Nagar R (eds.) Critical Transnational Feminist Praxis. New York, SUNY Press:105-123.

Pickles J (Ed.) (1995) Ground truth: the social implications of Geographic Information Systems. New York/London: The Guilford Press.

Power M and Sidaway JD (2004) The degeneration of tropical geography, Annals of the Association of American Geographers 94:585-601.

F. Ferretti, 2019 "Between radical geography and humanism: Anne Buttimer and the International Dialogue Project", Antipode, 2019 early view: https://onlinelibrary.wiley.com/doi/full/10.1111/anti.12536 [author's pre-print version] 
Pratt G and Philippine Women Centre (2010) Seeing beyond the state: Toward transnational feminist organizing. In Lock A and Nagar R (eds.) Critical Transnational Feminist Praxis. New York, SUNY Press:65-86.

Rose-Redwood R, Kitchin R, Rickards L, Rossi U, Datta A and Crampton J (2018) The possibilities and limits to dialogue. Dialogues in Human Geography 8(2):109-123.

Seamon D and Lundberg (2017) Humanistic geography. In D Richardson, N Castree, MM Goodchild, A Kobayashi, W Liu and RA Marston (eds) The International Encyclopedia of Geography (pp. 1-11). Hoboken: Wiley https://doi.org/10.1002/9781118786352.wbieg0412 Sharp J (2009) Humanistic geographies. In D Gregory, R Johnston, G Pratt, MJ Watts and S Whatmore (eds) The Dictionary of Human Geography (pp. 356-358). Chichester: WileyBlackwell.

Smith JM (2009) Humanism/Humanistic geography. In R Kitchin and N Thrift (eds) The International Encyclopedia of Human Geography (pp. 239-250). London: Elsevier.

Springer S, White R, Lopes de Souza M (eds) (2016) The Radicalisation of Pedagogy. Anarchism, Geography and the Spirit of Revolt. New York: Rowman \& Littlefield Tuan YF (1976) Humanistic Geography. Annals of the Association of American Geographers 66(2):266-276.

F. Ferretti, 2019 "Between radical geography and humanism: Anne Buttimer and the International Dialogue Project", Antipode, 2019 early view: https://onlinelibrary.wiley.com/doi/full/10.1111/anti.12536 [author's pre-print version] 